UDC 336.64

DOI: https://doi.org/10.32840/2522-4263/2020-5-28

Stefaniv Ihor

PhD in Economics,

Associate Professor of Department of Financial Management and Insurance of

Western Ukrainian National University

ORCID: https://orcid.org/0000-0003-2026-9835

Стефанів I.Ф.

кандидат еконолічних наук, доцент кафедри фінансового ленеджленту та страхування Західноукраїнського національного університету

\title{
THEORETICAL ASPECTS OF FINANCIAL STABILITY LEVEL'S MANAGEMENT OF THE ENTERPRISE
}

\section{ТЕОРЕТИЧНІ АСПЕКТИ УПРАВЛІННЯ РІВНЕМ ФІНАНСОВОЇ СТІЙКОСТІ ПІДПРИЕМСТВА}

\section{ANNOTATION}

Scientific approaches to defining the essence of the concept of "financial stability" are generalized. The structure of its factors is described. Various forms and methods of managing financial stability, the results of reducing its level are investigated and analyzed. The mechanism of maintaining a high level of financial stability for a long period of time is revealed. Methods of increasing the level of profitability of business entities are characterized. The methodological foundations of the efficiency of enterprise capital management are considered. Mechanisms for stabilizing financial flows are proposed. The main principles of optimization the processes of management of production factors, financial and investment risks have been formed. Mechanisms for stabilizing the profitability of an enterprise in conditions of uncertainty have been improved.

Key words: finance, financial resources, financial stability, financial methods, efficiency.

\section{АНОТАЦІЯ}

У статті узагальнені наукові підходи до сутності поняття «фрінансова стійкість», описані фрактори, що впливають на неї. Досліджені форми і методи досягнення максимального рівня ефрективності діяльності, утримання його впродовж тривалого періоду часу. Розглянуті напрямки стабілізації дохідності, оптимізації операційних витрат, рівня прибутковості, шляхи отримання ефекту фрінансової нормалізації, за якого можливо знижувати валові витрати, формуючи додатковий фінансовий потенціал для майбутнього розвитку. Проведена оцінка зовнішніх факторів, що породжують процеси реструктуризаціі і нерідко призводять до значних витрат, відповідних методів реагування. Висвітлені основні принципи формування ефективної системи управління капіталом, яка здатна допомогти суб'єкту господарювання досягати поставлених цілей, шляхи реалізації стратегії власного розвитку, форми її забезпечення достатньою кількістю ресурсів. Акцентовано увагу на необхідності формування механізму раціонального використання активів підприємством 3 одночасним виконанням задання щодо оптимізації прибутковості, нормалізації процесів відтворення 3 метою нарощення доходу. Означені методи диверсифікації джерел фінансування компаній з метою стабілізації потоків грошових та матеріальних ресурсів, форми реструктуризації розбалансованих виробничих систем, контролю за оптимальним рівнем витрат та отриманням прийнятного рівня ліквідності капіталу. Розглянуті різнорідні негативні ефекти втрати фрінансової стійкості, методи підвищення вартості та ліквідності активів, оптимізації боргів, підвищення рівня платоспроможності, пришвидшення оборотності ресурсів. Описані переваги використання комплексних методів управління капіталом, що призначені нормалізувати виробничу систему та підвищити ефективність процесів формування та використання ресурсів, принципи створення резистентної до зовнішніх факторів системи управління бізнесом, ефективного розміщення ресурсів в обороті з метою формування функціонального зв'язку між структурою актів та основними цілями і завданнями підприємства.

Ключові слова: фінанси, фінансові ресурси, фінансова стійкість, фрінансові методи, ефективність.

\section{АННОТАЦИЯ}

Обобщены научные подходы к определению сущности понятия “финансовая устойчивость". Описана структура ее факторов. Исследованы и проанализированы различные формы и методы управления финансовой устойчивостью, результаты снижения ее уровня. Раскрыт механизм удержания высокого уровня финансовой устойчивости в течение длительного периода времени. Охарактеризованы методы повышения уровня рентабельности субъектов хозяйствования. Рассмотрень методологические основы эффективности управления капиталом предприятия. Предложены механизмы стабилизации финансовых потоков. Сформированы основные принципы оптимизации процессов управления фракторами производства, финансовыми и инвестиционными рисками. Усовершенствованы механизмы стабилизации доходности предприятия в условиях неопределенности.

Ключевые слова: финансы, финансовые ресурсы, финансовая устойчивость, финансовые методы, эффективность.

Problem statement. Each business entity tries to achieve the maximum level of efficiency of its own activities and maintain it for a long period of time. This is one of his most important tasks. In that case, if the company manages to stabilize revenue and find an acceptable level of operating costs, it is possible to optimize the level of profitability. As result the effect of financial normalization will be created, under which it is possible to reduce gross costs, gaining additional financial potential for future development. Business costs become lower, the process of planning and capital management - more predictable, resources - cheaper, stable relationships with other businesses will be formed, reducing the level of risks. Then long-term development, effective capital management, rational business conduct, development of relations with other business entities are possible. 
Taking steps in this direction in practice, companies are faced with the fact that the process of forming and maintaining a sustainable income requires considerable effort, as the external economic environment is constantly demanding changes, which generates restructuring processes and often leads to significant costs.

The ability of company to achieve its goals, regardless of the type and strength of external factors determines its financial stability.

The more stable the company, the easier it is to adapt to changes, the lower the risks, the lower the losses from the influence of external factors. In this case, we can talk about an effectively formed management system that can help the business entity to achieve its goals.

Analysis of recent research and publications. Considerable attention to the problem of financial stability of enterprises was paid by such scientists as: I. Blank, K. Izmailova, G. Kireitsev, O. Pavlovskaya, A. Podderogin, N. Slobodyan, N. Tarasenko, etc. They have formed a general system for evaluating the effectiveness of enterprises activity.

Selection of previously unsolved parts of the overall problem. However, the effectiveness of financial stability management processes in conditions of uncertainty has not been given enough attention, which necessitates a deeper understanding and better study.

The purpose of the article is to study the theoretical aspects of the process of optimizing the level of financial stability of economic entities and the formation of criteria for their evaluation.

Presentation of the main research material. If an entity wants to achieve financial stability, it must act on the basis of a clearly formalized strategy of its own development, in accordance with its own goals. For this the sufficient amount of resources for current activities and investments must be provided. In the case when it is possible to achieve such a state, it can be argued that the overall efficiency is acceptable, resources are used rationally, liquidity of capital is sufficient to accelerate its turnover, the company has successfully organized its own activities.

The company's ability to rationally use capital, optimizing a profitability indicates that its reproduction process is normalized and nonproduction processes stimulate a revenue growth. The business entity quickly sells its own products, skillfully manages debts, successfully controlling its own cash flows. As a result, it carries out operational activities without undue effort, using methods to diversify its sources of funding.

On the other hand, if economic activity is unbalanced, it is difficult to maintain a stable income, while maintaining the optimal level of costs and an acceptable level of liquidity, as a significant part of monetary resources is

used for normalization processes. The process of intensification is stopped, the amount of investment resources is reduced.

Loss of financial stability can lead to the formation of heterogeneous negative effects.

To prevent these problems, economics advises the use of comprehensive methods of capital management, designed to normalize the production system and increase the efficiency of the formation and use of resources. At the same time, the pace of development of the entity can be accelerated when the external environment is sustainable and helps to increase the turnover of resources, improve production processes, introduce new methods of asset management, use modern technologies, innovations. Then there are all the prerequisites for rapid development.

It should be noted that any business entity is not able to receive a stable income for a long time, constantly adapting to changes in the external environment, which complicates the process of achieving goals, maintaining a high level of competitiveness, which demands the methods changes of functioning in the economic system. Under such circumstances, companies try to form a business management system that is resistant to external factors.

Every entity that wants to work in the market for a long time should try to achieve the optimal level of profitability and maintain it, stabilizing costs, normalizing risks. In practice, it can be achieved through the efficient allocation of resources in circulation, functionally linking the structure of assets with the main goals and objectives. At the same time, attention is paid to the processes of optimizing the formation and use of financial, material and information resources, avoiding unjustified losses, that accelerates their turnover, maintaining a high level of their liquidity.

In general, the main features of financial stability are manifested in the fact that the entity is able to effectively dispose of capital that 
is available for the implementation of current activities, for investment. It can be argued that a stable financial position is achieved not only through the efficient use of available resources, providing the ability to maneuver them quickly, but also through the ability to continuous development, using own potential.

In summary, we can say that financial stability the ability of an entity to operate effectively in a constantly changing environment, while maintaining the optimal level of profitability, liquidity, cost of factors of production, as well as the effectiveness of management system over a long period of time, while achieving tactical and strategic goals.

Some economists believe that the economic stability of the enterprise - is its competitive advantages in the market, others hold the view that financial stability is a certain state of its finances [8, p. 241]. In our opinion, financial stability is the result of the optimal type of behavior, effectively formed financial policy, which guarantees the constant development for company, the ability to achieve planned goals.

We agree that a company that has formed a stable financial system has an advantage over competitors in the market. Resources for it are cheaper, relations with other entities are more elastic, investment funds are formed faster and in larger volumes; it is easier to accumulate factors of production and maintain them at the appropriate level of liquidity, with additional financial protection against the effects of heterogeneous risks. Such business entities are able to function effectively, cooperating with other enterprises and organizations, ensuring the realization of their own goals. The sustainability of the economic component stimulates the emergence of an optimal system of resource circulation; production and non-production processes are more predictable, the company increases the pace of development, providing an increase in equity.

Financial stability also depends on the state of functioning of internal processes of the business entity, which are aimed at normalizing the system of resource turnover. It can be achieved through the modernization of production technology, forms of asset management.

Carrying out activities in the direction of increasing the efficiency, the business entity must focus not only on achieving the current stable state, but also on its formation in the future. There are two approaches. For the first, the company connects the level of future resilience to the current, functionally linking resources, financial and economic processes. Using the second current and future financial stability it aligns with strategic goals. The first method is simpler: it allows to accurately control the processes of resource turnover, but the effectiveness of the strategic goals of the company will be low.

To form the desired level of financial stability, the entity must have a certain number of factors of production. What is important here is how much resources we must use to provide this level. Sub-optimal level of funding leads to losses. In general, such state is inefficient when resources are used directly to maintain solvency and financial stability. In this case, they are withdrawn from circulation and do not bring a revenue.

Each company must independently form the optimal structure of factors of production in accordance with its own purpose, the specifics of the activity, to develop methodological bases for asset value management, taking into account the priority of investment programs. The main attention is paid to the processes of stabilization of own activity. And here there are no equal approaches to the formation of the optimal level of financial stability for all enterprises. The process of creating subjective standards in this matter is quite complex. But in most cases, the optimal level of solvency and financial stability can be achieved by stabilizing financial flows. The relatively constant level of incoming and outgoing cash flows of the entity indicates that asset turnover transactions have been normalized, a certain level of efficiency of all actions has been achieved.

If the liquidity of capital is high, then there is an opportunity to quickly maneuver resources, expanding the business, diversifying activities. In this case, part of the assets can be used to reduce the risk of transactions.

Sustainable resource turnover is not a guarantee that it will continue to be the same. No company is safe from problems in the future. The external environment is constantly changing, the rules of economic system are becoming more complicated, the level of intensity of economic activity is not a constant value. However, having the latest information, skillfully using it, improving methods of managing assets, the company can control its own financial stability, assess the factors that can negatively affect it and using effective methods to neutralize them.

An additional factor of increasing the dynamics of development may be the process of stabilizing the operating costs while maintaining the qualitative and quantitative characteristics of the production cycle. Then it is possible to release some of the resources from the operating cycle and direct them to the investment sphere.

There are a number of factors that have an overall impact on the processes of stabilization of financial activities. In most cases, the current financial stability is possible due to the efficient allocation of resources, and the future - due to the release of some current resources and their transformation into investment funds. This approach allows to develop the business more systematically, avoiding significant risks. It also allows to control more effectively cash flows and forecast the results of activities.

In the case, if part of the resources is removed from current operations in order to 
ensure the future effect of stabilization, the rate of development decreases slightly. Then each individual business entity must take care to increase the liquidity of capital, and by increasing turnover to cover temporary losses.

Factors that have an overall impact on the processes of financial activities stabilization:

- typology of processes of economic system formation;

- form of informatization of the business entity;

- selected goals, methods of their implementation;

- type of relationship with the external environment.

To achieve main goals, the company must have an appropriate structure of factors of production. Here we are talking not only about their optimal cost, but rather about their types and functionality. If an entity has failed to select the appropriate structure of factors of production, its strategic objectives will either be delayed or not implemented at all. This situation will reduce the level of its financial stability and solvency. And here the focus should be on the efficiency of the production system. It is this component that determines the typology of the resource management system, equity and debt capital. The speed and level of achievement of goals depends on it. In order to accelerate the process of realization of own goals, the production system must structurally correspond to the general goals, stages of realization the own tasks.

The debt management system has a significant impact on the overall level of productivity and sustainability of the business entity. Effectively formed, it accelerates the turnover of resources, increasing their value, and due to the effect of scale increases the profitability. Successfully selected methods of managing receivables and payables allow timely payments, normalizing the level of financial relations, the cost of resources in circulation and the level of their liquidity, which has a positive effect on the level of financial stability. On the other hand, increasing the amount of external resources causes a high level of dependence of the enterprise and, as a consequence, creates the preconditions for loss of financial stability. In this case, we can use methods to optimize the capital structure, taking into account a level of operational risk. At the same time, structural changes in assets should lead to an increase in their liquidity.

Domestic science today offers various methods for assessing financial stability, including direct and factorial, that allow to obtain the desired data for a specific date. We believe that factor analysis of level of resources management efficiency is more valuable in order to assess the optimal level of financial stability. Here it is necessary to assess which expenses generate income for the company and which do not. In this case, the assessment should be made taking into account the correlation between past or current expenses and current or future income. By combining this approach with the use of the integral method, it is possible to assess the stability of correlations between the structure of income and expenses.

Conclusions. Today there are a number of approaches to assessing the financial stability of a business, which indicates the complexity of this problem. In our opinion, the most promising direction is in which the level of financial stability will be assessed by factorial and complex methods. With their help, it is able more accurately determine which costs increase the company's revenue, as well as more accurately plan the future level of profitability and financial stability.

\section{REFERENCES:}

1. Aleksejenko L.M. (2004) Rynok finansovogho kapitalu: stanovlennja, problemy, perspektyvy rozvytku: monoghrafija [Financial capital market: formation, problems, development prospects: monograph]. Ternopil: Ekonomichna dumka. (in Ukrainian)

2. Ghudzj O.J. (2011) Diaghnostyka ta upravlinnja platospromozhnistju v aghrarnykh pidpryjemstvakh [Diagnosis and management of solvency in agricultural enterprises]. Stalyj rozvytok ekonomiky, no. 7 (10), pp. 323-326.

3. Donchenko T. (2010) Teoretychni osnovy formuvannja mekhanizmu upravlinnja finansovoju stijkistju pidpryjemstva [Theoretical bases of formation the mechanism of management of financial stability of the enterprise]. Visnyk Khmeljnycjkogho nacionaljnogho universytetu, no. 1, pp. 23-27.

4. Kejns D. (2007) Obshhaja teoryja zanjatosty, procenta y denegh [General theory of employment, interest and money]. Moskva: Eksmo. (in Russian)

5. Masjuk Ju.V. (2011) Osoblyvosti optymizaciji upravlinnja kapitalom v umovakh kryzy [Features of optimization of capital management in a crisis]. Naukovyj visnyk Uzhghorodsjkogho universytetu. Specvypusk 33. Ch. 2, pp. 181-185.

6. Partyn Gh.O. (2010) Osoblyvosti vplyvu osnovnykh chynnykiv na finansovu stijkistj pidpryjemstva $v$ umovakh finansovoekonomichnoji kryzy [Features of the influence of the main factors on the financial stability of the enterprise in the financial and economic crisis]. Zbirnyk nauk.-tekhn. pracj Nacionaljnogho lisotekhnichnogho universytetu Ukrajiny, no. 10 , pp. $276-279$

7. Semenov A.Gh. (2010) Pobudova modeli efektyvnogho upravlinnja strukturoju kapitalu pidpryjemstva [Building a model of effective management of the capital structure of the enterprise]. Visnyk Zaporizjkogho nacionaljnogho universytetu, no. 2 (6), pp. 78-83

8. Slobodjan N. (2014) Analiz i proghnozuvannja finansovoji stijkosti pidpryjemstva v suchasnykh umovakh: metodologhija i praktyka [Analysis and forecasting of financial stability of the enterprise in modern conditions: methodology and practice]. Ekonomichnyj analiz: zbirnyk naukovykh pracj, no. 18, pp. 239-245.

9. Shirinjan L.V. (2005) Vyznachennja finansovoji stijkosti strakhovykh kompanij i pidpryjemstv [Determining the financial stability of insurance companies and enterprises]. Finansy Ukrajiny, no. 9 (118), pp. 70-80. 
10. Shumylo I. (2006) Teoretychni i praktychni aspekty analizu stanu finansovoji systemy ekonomiky [Theoretical and practical aspects of the analysis of the state of the financial system of the economy]. Visnyk NBU, no. 3, pp. 6-11.

\section{БІБЛІОГРАФІЧНИЙ СПИСОК:}

1. Алексеєнко Л.М. Ринок фінансового капіталу: становлення, проблеми, перспективи розвитку : монографія. Тернопіль : Економічна думка, 2004. 424 с.

2. Гудзь О.Є. Діагностика та управління платоспроможністю в аграрних підприємствах. Сталий розвиток економіки. 2011. № 7 (10). С. 323-326.

3. Донченко Т. Теоретичні основи формування механізму управління фінансовою стійкістю підприємства. Вісник Хмельницького національного університету. 2010. № 1. T. 1. C. 23-27.

4. Кейнс Д. Общая теория занятости, процента и денег. Москва : Эксмо, 2007. 960 с.
5. Масюк Ю.В. Особливості оптимізації управління капіта-лом в умовах кризи. Науковий вісник Ужгородського універcumemy. 2011. Спецвипуск 33. Ч. 2. С. 181-185.

6. Партин Г.О. Особливості впливу основних чинників на фрінансову стійкість підприємства в умовах фрінансовоекономічної кризи. Збірникнаук.-техн. праць Націо-нального лісотехнічного у-ту України. 2010. № 10. С. 276-279.

7. Семенов А.Г. Побудова моделі ефективного управління структурою капіталу підприємства. Вісник Запорізького національного університету. 2010. № 2 (6). С. 78-83.

8. Слободян Н. Аналіз і прогнозування фінансової стійкості підприємства в сучасних умовах: методологія і практика. Економічний аналіз : зб. наук. праць Терноп. нац. екон. $y$-my, 2014. Том 18. № 2. C. 239-245.

9. Шірінян Л.В. Визначення фінансової стійкості страхових компаній і підприємств. Фінанси України. 2005. № 9 (118). C. $70-80$.

10. Шумило І. Теоретичні і практичні аспекти аналізу стану фінансової системи економіки. Вісник НБУ. 2006. № 3. С. 6-11. 